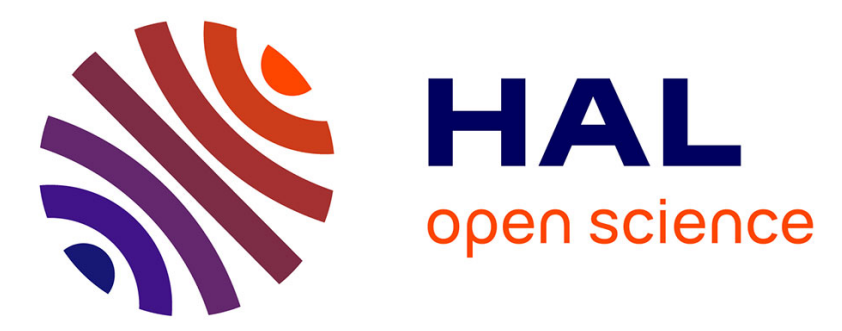

\title{
The contribution of animal production to agricultural sustainability
}

\author{
Michel M. Doreau, Harinder P S Makkar, Philippe Lecomte
}

\section{To cite this version:}

Michel M. Doreau, Harinder P S Makkar, Philippe Lecomte. The contribution of animal production to agricultural sustainability. 4th International Symposium on energy and protein metabolism and nutrition (ISEP), Sep 2013, Sacramento, United States. hal-02745913

\section{HAL Id: hal-02745913 \\ https://hal.inrae.fr/hal-02745913}

Submitted on 3 Jun 2020

HAL is a multi-disciplinary open access archive for the deposit and dissemination of scientific research documents, whether they are published or not. The documents may come from teaching and research institutions in France or abroad, or from public or private research centers.
L'archive ouverte pluridisciplinaire HAL, est destinée au dépôt et à la diffusion de documents scientifiques de niveau recherche, publiés ou non, émanant des établissements d'enseignement et de recherche français ou étrangers, des laboratoires publics ou privés. 


\title{
The contribution of animal production to agricultural sustainability
}

\author{
M. Doreau ${ }^{\text {I }}$ H.P.S. Makkar ${ }^{2}$ and P. Lecomte \\ ${ }^{1}$ INRA, UMR Herbivores, 63122 Saint-Genès Champanelle, France; michel.doreau@clermont.inra.fr \\ ${ }^{2}$ Animal Production and Health Division, FAO, Rome, Italy \\ ${ }^{3}$ CIRAD, UMR SELMET, 34398 Montpellier, France
}

\begin{abstract}
Due to the increasing demand for animal products for a growing world population, use of a large amount of feed ingredients in competition with human food coupled with the urgent need for mitigating environmental effects, livestock farming has to transform. New models of sustainability, that are acceptable to all stakeholders, must be explored. Reducing negative environmental impacts of various agricultural practices is a major global challenge. However, to avoid making inappropriate decisions, sustainability should be understood and addressed by combining indicators that are relevant at farm, country and world levels and not solely based on the emission of greenhouse gases. Sustainability has to go beyond productive efficiency, embracing eco-efficiency concepts and including social equity, and ethical dimensions of development. There is a large diversity of systems, from low-productive or extensive to high-productive or intensive, and countries are at different stages of development, from developing, fast developing to developed. Hence solutions are likely to be very different. Co-existence of different livestock production systems and addressing their sustainability using multiple indicators is a key to success.
\end{abstract}

\section{Introduction}

Livestock farming enters a paradoxical situation. In a changing context, marked by escalating costs of inputs, decreasing natural resources and ongoing climate change, livestock production systems have to transform in the short- to medium-term. For the expected 9 billion people by 2050 the world will need to produce much more food with the same agricultural area, or with a smaller area, if the ongoing soil degradation is not abated and/or biofuel production keeps growing. Increases in income and urbanization in emerging countries and resulting changes in food habits lead to inclusion of a higher amount of animal-source foods (meat, milk, eggs) in the diet of humans (FAO, 2009). Transformation of biomass into edible animal foods has a lower efficiency than direct vegetal food production. The former requires more natural resources per MJ of energy or kg of protein yield, and thus leads to higher emissions. The desire to protect environment and biodiversity, and to improve animal well-being are raising new questions regarding the manner by which animal foods are being produced or will be produced. For example, how can the increase of the current production be considered while reducing environmental effects and maintaining equity in the recognition and sharing of economical and social impacts of the goods and services produced through livestock? How can animal agriculture be made a driver for agricultural sustainability? In the future, countries and societies will prioritize objectives of producing livestock differently, depending on factors such as income levels, role of smallholders relative to large scale producers, importance of and prospects for import or export, degree of pressure on, and degradation of, natural resources, and social and ethical concerns. The objectives will be prioritized differently according to the country's stage of economic development. Addressing these divergent goals is a challenge for the next decades.

Livestock systems, which are very diverse throughout the world (Robinson et al., 2011), should take better into account the efficiency with which natural resources, carbon, nitrogen and energy, as well as human and animal resources are used to produce goods and provide multiple functions in diverse landscapes. There is currently a major societal debate on both positive and negative impacts of livestock production and their future capability to provide ecosystem services. The differentiated role of intensive, mixed crop-livestock and extensive or low-input systems, their 
productive performances in context to their natural, renewable or non-renewable resource use, social contributions and environmental impacts, are often controversial and challenging subjects. Across the world, the diverse agro-ecological contexts present a wide spectrum of assets and constraints, resulting in geographical diversity of livestock farming systems performing multiple functions in the territories where they developed. Sustainability indicators for such diverse systems should be broadened and balanced, to go beyond traditional assessments of productive performance.

\section{Sustainability in agriculture - a concept difficult to arrive at a consensus}

The classical definition of sustainability demands balance amongst three pillars corresponding to environmental, economic and social issues. Criteria for their assessment are numerous, and there is no consensus on their applicability. Environmental issues include the use of natural resources and its impacts on the environment. An obvious natural resource capital is land, the use of which for agriculture is increasingly becoming limiting, despite a recent and extensive deforestation of primary forest and the presence of still large uncultivated areas, for example in Siberia. In addition, on arable land there is an increasing competition between the production of human food, animal feeds and biofuels. Other natural resources used by agriculture are either non-renewable (e.g. fossil energy or phosphorus) or renewable but vulnerable (e.g. freshwater). In the latter case, a shortage has consequences on global ecosystems and human activities. Environmental impacts may be global, e.g. greenhouse gases (GHG) are emitted in the world's atmosphere, wherever they are produced; however, other impacts are restricted to a small territory or a watershed, e.g. soil and water pollutants. Social issues do not have the same meaning in developed and developing countries, in rural and urban societies. Lebacq et al. (2013) distinguished social issues based on farm-targeted criteria (working conditions, education, way of life) and society-targeted criteria (multifunctionality, acceptability of agricultural practices, quality of products). A common point to all social issues is the difficulty in finding an agreement amongst stakeholders for the criteria and then giving them relative weights. Economic evaluation is generally done in terms of profitability, a short-term criterion, whereas it should also consider macro-economic changes and future agricultural policies, as well as resilience to climatic and market hazards. In addition, the functional expression of income is extremely variable, and can be calculated per unit of product, or per hectare on-farm, or on-farm plus off-farm, etc. with different conclusions for profitability according to the unit chosen.

The mandatory need to feed 9 billion people requires addressing trade-offs between sustainability at farm level and at global level. The efficiency of production is not given due consideration in some production systems. For example, it is unclear whether low-input diets with a low animal productivity, which may provide a good income to the farmer (e.g. organic farming), are sustainable at a large scale for providing food to fast developing countries. It is also necessary to integrate natural changes, such as the effect of climate change on agriculture (change in crop yield, in crop species) and the adaptive capacity of animals which may help to cope with these changes. Breeds/species which were the most adapted may be less adapted to different natural conditions in future.

Addressing the environmental issues in many developing and transition countries is important but it does not divert focus from the main objective which is to increase the national production for meeting the increasing food needs. The social importance of family households (farmers) becomes low at the expense of urban society in many developed countries, whereas in the least developed countries smallholders who represent a major proportion of the population play a central role. Most societal issues related to environment, security and welfare are of higher importance for countries with consumers having a high standard of living. Attaining well-being of the agricultural community is aimed throughout the world but with large differences among countries due to differences in their developmental stage. There is a need to go beyond the sustainability assessment of existing systems, and to redesign systems for the long term by anticipating economic, social and environmental tradeoffs and shocks that will come from future development of the global production. Table 1 proposes 
Table 1. Criteria for agricultural sustainability: their nature and importance differ according to the level where they are considered (only a selection of criteria has been mentioned).

\begin{tabular}{llll}
\hline & Environment & Social & Economic \\
Farm level & Use of organic manure & $\begin{array}{l}\text { Human well-being } \\
\text { Increasing livelihood } \\
\text { Cultural role of animals }\end{array}$ & $\begin{array}{l}\text { Profit } \\
\text { Resilience }\end{array}$ \\
\hline $\begin{array}{llll}\text { Country or territory National GHG inventory } \\
\text { level }\end{array}$ & $\begin{array}{l}\text { Employment } \\
\text { Soil and water pollution } \\
\text { Use of water }\end{array}$ & $\begin{array}{l}\text { Animal welfare } \\
\text { Food security }\end{array}$ & Food sovereignty \\
\hline World level & Use of natural resources & Reduction in poverty & Achieving production \\
& Air pollution & & target \\
& Land use, deforestation & & \\
\hline
\end{tabular}

a set of sustainability criteria to address issues at different levels, from local level (the farmer) to world level (planet and mankind).

\section{Animal production and the environment}

A significant part of the environmental impact and intensive use of non-renewable resources are related to food production. The role of livestock in greenhouse gases (GHG) emissions, water and soil pollution, loss of natural resources and of biodiversity, among others, has been stressed by FAO (Steinfeld et al., 2006). As farm animals consume plants, animal-source foods have a higher environmental impact than vegetal food per $\mathrm{kg}$ of edible product. In addition, a significant part of GHG emissions comes from enteric methane produced by ruminants. Comparing impacts based on GHG emission per kg of product might not be appropriate, because of differences in dry matter, energy and protein contents of products. So making comparison based on energy or protein yield is expected to give a better insight. Nevertheless, Vieux et al. (2012) surprisingly showed that replacing meat with fruit and vegetables on an iso-caloric basis did not decrease total GHG emissions. A comparison on an energy basis does not account for a major specificity of animal foods, which is protein supply. The expression per kg of protein is especially useful to compare milk, eggs and meat of different origin. It has thus been shown that all impacts (GHG, eutrophication, energy and land use) per $\mathrm{kg}$ protein are higher for beef than for other animal products (Gill et al., 2010, De Vries and de Boer, 2010). What is often questioned about livestock production is that the products derived from $35 \%$ of arable land are consumed by animals largely as feeds. This land could have been used for producing food for direct consumption by humans. It is a simplistic view because a large part of these products are co-products and by-products which are human non-edible. Moreover livestock and their feeds also provide a buffer in national and international markets, which can be drawn upon in case of food shortages. In the previous world food crises of the last 4 decades 1974/75 and $1981 / 82$, overall grain supplies to animal sector fell significantly at world level (FAO, 2009). In addition, many geographical areas, such as mountains and rangelands, are covered by grass because they are not suitable for crop production.

High water demand of livestock is often cited as a major environmental issue. A frequently cited figure is 15,000 liters of water needed to produce one $\mathrm{kg}$ of beef. This calculation includes 'green' water, i.e. water need for producing plants which are consumed by animals. Plant water need corresponds to evapotranspiration, which is positively related with crop/forage yield and rainfall. As a consequence, extensive systems require the largest amounts of water, because they need large land areas. Such a calculation is made independent of water scarcity: when including green water, the water requirement for world annual beef production is higher than the world's freshwater reserves 
(Doreau et al., 2012). In order to determine the effective impact of livestock on water resources, recently improved methodologies have been developed. They use a life cycle assessment (LCA) approach, and consider only blue water, i.e. water consumed as liquid by the animals and on-farm water use for servicing and irrigation to produce feeds. Some of the authors propose a weighted value accounting for the risk of water reserve depletion (Kounina et al., 2013).

Animal production has also positive effects on the environment. In developed countries, it often adds to the quality of landscape for urban people. In developing countries, an adequate manure management restores soil fertility in crop-livestock systems, and in pastoral areas management of grasslands is a unique way to use soil and to protect it against erosion (Blanfort et al., 2011). These environmental services are often difficult to take into account because the value of the quality of landscapes with natural grasslands compared to cereal fields, for example, is difficult to quantify, e.g. in monetary terms. Recently, in a LCA approach, two groups of authors (Nguyen et al., 2012b, for French beef; Ripoll-Bosch et al., 2013, for Spanish lamb) made an economic allocation between income from selling meat and from subsidies targeted on the use of low-fertilized grasslands from this production, and on the multi-functionality of livestock. These initial attempts, though commendable, need to be improved.

As a partial solution to the livestock-related environmental issues, rationalisation of consumption of animal products is an option. This would consist of a decrease in animal product consumption by people in developed countries and by high- and middle-income classes in urban areas in the fast developing economies and an increase in consumption by those living in developing countries particularly in Africa where the animal product consumption is very low. However, this will not solve the problem, as consumption is expected to increase in developing countries, resulting in a substantial increase in GHG emissions from the livestock sector in these countries, although the GHG emission will stabilize in developed countries (FAO, 2009). The need for improving production efficiency, for example by improving animal breeding, nutrition and health, could help to limit the environmental impact of the livestock sector (Thornton, 2010).

\section{Challenges in reducing environmental impacts from animal production}

During the last decade many studies aimed at finding ways to reduce environmental impacts, using different approaches, among them LCA being the most used, have been conducted. These studies were either on partial systems (fattening bulls or pigs, animals on pasture) or complete systems (beef herd in a whole year, total pig production for a whole year). Results were very diverse, because of differences in the system boundaries used in the LCA methodology, in the origin of the data, in the emission allocation methods and in the choice of emission/pollution factors. Large difference among systems or countries exist (FAO, 2010 for milk; Basset-Mens and van der Werf, 2005 for pig), but within a system application of an array of options requiring important changes in the system are necessary to considerably decrease impacts (Nguyen et al., 2013 for beef). However, between-farm comparisons show large differences for the same system (Doreau and Dollé, 2011 for GHG in dairy farms): acquisition of good environmental practices by farmers is a first step. There are a lot of public recommendations for decreasing emissions especially GHGs (UNFCCC, 2008) but they are often unstructured and do not account for interactions between options and trade-offs between impacts. A valuable tool for policy makers is the establishment of marginal abatement cost curves which combine the efficiency of options and their cost on a long-term perspective (Moran et al., 2008). However, finding the best available options may be hampered by the lack of accurate knowledge of technical efficiency, and the difficulty to predict economic trends and prices in the future. Once options are identified, policy makers have two major instruments at their disposal: changes in taxes and subsidies structure, differing in nature and efficacy (Gerber et al., 2010). 
For a few years, many countries focused their efforts on reducing GHG emissions, which emerged as an enormous challenge due to the on-going global warming and need for an immediate answer. The use of non-renewable energy and of the phosphorus, or localized degradation of water quality also required urgent actions. An intervention that reduces one impact may increase another one in production systems; for example cattle fattening diets are ranked differently for GHG emissions, eutrophication and energy use (Nguyen et al., 2012a). Organic farming leads to lower changes than conventional farming in GHG emissions per kg milk, because the higher methane emission due to lower cow productivity is compensated for by lower nitrous oxide and carbon dioxide emissions due to lower inputs. Other impacts such as eutrophication and acidification potential or energy use are generally lower for organic farming in ruminants (De Boer, 2003); differences are less marked for pig meat (Basset-Mens and van der Werf, 2005) because crop yields and pig growth rates are lower in organic farming.

When impacts are expressed per ha instead of per $\mathrm{kg}$ of animal product, comparison between farming systems give widely different results. Impacts per ha are lower for grass-based extensive systems including organic farming. This unit is useful for a territorial approach, when the objective is for example to reduce pollution at a watershed level, or to reduce GHG in a national inventory. However, these systems result in an increase in land use. At a country level, increasing land use by livestock may be positive for local management, for example in mountain areas; but at world level it may result in deforestation of primary forest due to the pressure on land for agricultural activities if the global increase in food production is aimed at.

A largely debated issue is the extent of carbon sequestration by soils, especially pastures, which contributes to reducing net emissions of GHG. Permanent grasslands and no-tillage practices are efficient techniques. According to IPCC (2007) the increase in carbon sequestration by soils may contribute to $89 \%$ of GHG mitigation from agriculture by 2030 . Although this estimate appears excessive, integrating $\mathrm{C}$ sequestration in $\mathrm{GHG}$ balances should be more frequent; to our knowledge it has been done only for 2 years (e.g. Doreau et al., 2011) but the amount of carbon storage per ha of grasslands that has been measured in these studies is extremely variable (from 0.12 to $2.5 \mathrm{~T}$ $\mathrm{C} /$ ha per year); moreover when crops or leys replace permanent grasslands there is a $\mathrm{C}$ release. In order to account for both existence of $\mathrm{C}$ sequestration and criticisms relative to uncertainty, it may be recommended to present first GHG raw emissions then GHG balance due to land use and land use change, which comprises the effect of $\mathrm{C}$ storage or release, and the effect of deforestation of primary forest when soybean is used.

Most agricultural LCA are established from the cradle to the farm gate; environmental cost of product processing, distribution, domestic use and waste recycling are seldom taken into account. These processes increase environ:nental costs, especially energy use and GHG emissions; post-farm gate GHG are $17-22 \%$ and $1-10 \%$ of the total in industrialized and developing countries, respectively (FAO, 2010). Besides the calculation of impact per $\mathrm{kg}$ of produced foods, it is necessary to assess post-production losses. Food waste may go beyond $30 \%$ of production for dairy products and meat, especially in developed countries. Post-harvest grain losses have long been mentioned in developing countries; losses in animal-source foods have been less intensively studied but may be lower due to the importance of family or local consumption. For example in India the losses in animal-source foods are less than $5 \%$ of the production (Nanda et al., 2012). A recent paper stresses the risk of increase in waste in fast developing countries due to the rapid increase in food production (Parfitt et al. 2010). In developing countries, the main reason for waste is the lack of infrastructure and the low organizational level for trade and transport; while in developed countries, the marketing push of the supermarkets leading to excessive purchases by customers, the inability to sell foods before the expiry date by supermarkets, the level of demand by the consumer and non-consumption within the shelf life of the products are major sources of retail and consumer food losses (Hodges et al., 2011). 


\section{Sustainable animal production in the future}

Many studies show there is still underutilized potential to reduce the burden of the sector on the environment, and strengthen the positive role that the livestock sector may have in mitigating climate change, nutrient recycling, protection of biodiversity and the provision of other environment services. Significant progress can be made through the development of regulatory frameworks and incentives for environmental services. For extensive systems, the payment of environmental services such as carbon sequestration and biodiversity protection (for example through silvopastoral systems; see Murgueitio et al., 2011) are good examples. It has potential for application in many regions of the world e.g. Latin America and Africa. In intensive systems, more efficient use of inputs (water, nutrients, energy) through innovations in technologies and adaptation and improvement in the existing practices and/or restoration of strong linkages between livestock and crops can lead to obvious environmental gains. In economic terms, in a finite space where there is strong competition between agricultural and non-agricultural uses of land as well as among the crops themselves for use as human food, animal feed or industrial transformation processes, improving animal performance remains central to productive efficiency. The improvement in skills, knowledge, techniques and tools in the areas of animal genetics, feed and feeding, animal health and management and their use will help achieve the productive efficiency required to maintain the competitiveness of products and industries and to meet multiple expectations from livestock production.

In fast developing countries, aside from the traditional agricultural sector, the mobilization of public and especially private funds for land acquisition and realization of investments in structures of very large size, may help to develop new farming systems and contribute in these countries to increase production capacity and efficiency. These systems are different from the model that prevailed during the twentieth century in developed countries (EU, US, Canada, Japan, etc.) wherein the farm modernization and the growth in the quantity produced was made through specialization of family size farms. These development models will certainly be capable of competing, and will also be complementary to the dynamics that are created across the regions and the quality niches that they each address. However, it is likely that due to their size, which concentrates effluents in a same place, and sometimes to their financial objectives, these industry-like enterprises often raise environmental questioning.

Beyond the economic, environmental and societal assessments of the situations and of the stakes that will dictate the future, transforming knowledge and skills into practice, and using them to improve the efficiency of resource and land use for the sector growth is a major challenge. To address the complexity of issues raised for making changes in the operating practices in the livestock sector, it is necessary that all actors (from the primary resource producer to the consumer) get better connected. The different sources of knowledge to which they have access should lead to the adoption of new technologies for production as well as of new modes of consumption of animal products. This will require an even greater flow of knowledge and innovations among all stakeholders whether these are in developed or developing countries.

\section{Sustainability of low-productive livestock systems}

For low productive livestock systems, a major criticism is the environmental impact that they produce, especially when expressed as GHG emission per $\mathrm{kg}$ of product, milk or meat. The FAO (2010) compared GHG emissions for milk production in different countries. When annual milk yield is lower than $2,000 \mathrm{~kg}$, GHG emissions per $\mathrm{kg}$ increase rapidly. Since the full genetic potential of animals in the field is not realized (Cunningham, 2005), increase in productivity by improving animal nutrition, management and health practices will decrease GHG emission per unit of animal product. Also rearing a high genetic potential cow with $8,000 \mathrm{~kg}$ milk production per year in the areas that now produce $2,000 \mathrm{~kg}$ or less per year is also not a realistic option due to lack of feed resources and 
unsuitable climatic factors. Creating artificial conditions required to express full genetic potential of such high producing animals is not expected to be sustainable and increase the GHG emission per $\mathrm{kg}$ milk when GHG emission in the processes required to create the artificial conditions are taken into account. It may also be noted that low-productivity systems could also be economically viable due to low input costs. For smallholder livestock farmers in developing countries, a major pillar of sustainability is the social one. Indeed, livestock have a cultural role. Some societies as Peul or Masai cannot be dissociated from cattle herds. Beyond these specific cases, livestock farming (or crop-livestock farming) is essential for the livelihood of many rural communities in Africa, Asia or Latin America. Herds are a capital which may buffer cash flow problems. Animal gift and lending are a mechanism of solidarity for very poor people, and/or they contribute to a social network favoring interdependency between communities (Alary et al., 2012). In addition, livestock farming by smallholders also contributes to food security at country level, in addition to providing valuable minerals and vitamins to pregnant women and growing children. Owing to the lack of infrastructures for food transport, meeting locally the physiological needs and maintaining social equilibrium are of utmost importance, which animal husbandry offers to farmers. There is a need to better value these social dimensions the livestock play for such communities and bring them into the holistic equation of sustainability rather than labeling such systems unsustainable based on only GHG emission per $\mathrm{kg}$ of animal product.

Many farmers have very low income, either because of poor management of their farm (for example excessive inputs with regard to output) or because of unfavorable natural conditions, for example mountains or poor soils which lead to low crop and/or forage yields. The question is why to maintain livestock in such places where the production is less efficient compared with that in better natural conditions. From a social point of view, livestock maintains human presence, which would not occur in case of uncultivated land or forest. Moreover these areas do not compete with crops for use as human food or for biofuel production due to low productivity. The challenge is to improve economic profit, when farms are vulnerable to both climatic and economic shocks, such as drought and when there is drop in product price. For ruminants, the first solution is to take advantage of the high adaptive capacity of the animals, by alternating undernutrition and refeeding periods to decrease global feed cost (Blanc et al., 2006). Bio-economical modeling allows finding the most appropriate strategies; for examples for beef farms increasing purchased feeds and grass surface for haymaking are proposed for a better herd resilience (Mosnier et al., 2010). Darnhofer et al. (2011) recommend diversification of farm activities in order to improve resilience of the whole farm. Specific systems related to a territory sometimes may give an opportunity for producing niche products that consumers are ready to pay more, owing to a higher sensory quality or a unique geographical origin. Appropriately managed grazing land and supportive institutional and policy frameworks can enhance productivity and livelihoods in addition to providing large benefits in the form of carbon sequestration, protection of biodiversity and water services.

\section{Increasing sustainability in intensive systems}

Faced with the need to increase meat, milk and egg production, the development of intensive systems is often recommended (Steinfeld et al.,2006). The intensive model used for several decades aimed to increase production per animal or per unit of surface. However, it has become necessary to improve the environmental performance (sometimes called eco-efficiency) by decreasing inputs while maintaining or only slightly reducing productivity. For milk production, this is possible, for example, by reducing grass $N$ fertilization and stocking rate (Basset-Mens et al., 2009), by improving energy use efficiency through means of nutrition or genetic (Reynolds et al.,2011) or by drastically decreasing protein supply to animals (Fanchone et al., 2013). This is more difficult for pig and especially poultry production, but the use of synthetic amino acids decreases soybean use and thus environmental costs and land use change (Mosnier et al., 2011). There are other examples showing that technology or biotechnologies may help. However, sometimes, efficient biotechnological 
solutions are not acceptable from an ethical point of view or customer perception. This is the case for instance for phytase-producing transgenic pigs which help to reduce phosphorus losses, whereas phytase from fungal or bacterial origin is widely used. Another way to reduce inputs is to improve animal fertility and health. Unfortunately, animals with higher productivity have a higher sensitivity to various diseases; and in cows, there is a negative relation between animal productivity and fertility. These undesirable effects are due to the past genetic selection which aimed at only increasing yield. Genetic selection using other criteria, for example higher disease resistance, reproductive efficiency, and longer productive life, that help to increase efficiency of production should be targeted (Scollan et al., 2010). Also precision agriculture i.e. on-farm development of monitoring techniques (e.g. physical and chemical sensors, image and sound recordings, etc.) and provision of all inputs to the places and at times (using computerized tools) required by the animal, thereby maximizing resource use efficiency.

The realization of profitability of well-managed intensive systems leads to extreme situations: farms having a huge number of animals, and exploitation of animal potential by maximizing productivity. These farms are widespread in North America but are increasingly found in developing countries as well. In developing countries they compete with smallholders who do not have the same access to infrastructure and resources, and hence become extinct with time. Such farms limit imports of animal products but profit generally does not benefit the local population. In addition to raising these major social issues in developing countries, these huge intensive farms concentrate manure at one place with negative environmental consequences such as soil and water pollution if they are not managed properly. According to Scollan et al. (2010) good management of manure and use of biogas are attractive options to overcome these environmental problems.

It is worth noting that high productive farms may look sustainable based on GHG emission per $\mathrm{kg}$ animal product but might not be sustainable in the future due to increasing cost of cereals and fossil energy. Equally important is to consider animal welfare and ethical dimensions of feeding high grain diets to animals. Also, such systems disrupt the nitrogen cycle through transport of high amounts of soybean e.g. from Southern America to other parts of the world. In addition any disruption in trade or volatility of the cost of these feed inputs can be catastrophic for such farms. In order to address these issues, a recent approach promotes agro-ecology, a way to improve or to maintain efficiency by means of ecological solutions. Application of the principles of agro-ecology to livestock has been extensively described by Dumont et al. (2013). In addition to a decrease in inputs, agro-ecology advocates an increase in animal and vegetal biodiversity, the optimization of metabolic functioning of farming systems and an improvement in management for maintaining animal health. These techniques generally result in better sustainability and resilience to shocks (Thornton, 2010). A classical improvement of eco-efficiency based on technology and optimization of animal functions is not exclusive of an agro-ecological approach. It is applied in different systems. Some options are presented in Table 2.

The dependence on cereals in many countries of the South will grow and their use for animals will make the systems less resilient and more prone to food-feed-fuel competition. An improved use of fibrous materials, forages or industrial by-products (Bocquier and Gonzalez-Garcia, 2012; FAO, 2012) could reduce the dependence on cereals. The dynamics of concentration of livestock farming in peri-urban situations produces nutrient surplus and associated latent pollution in these areas. This is in addition to the other challenge of nutrient depletion in the rural areas. In the cropping systems, the loss of carbon as well as problems of fragility and fertility of tropical soils remains a major issue. These issues together with the rising cost of fertilizers and energy, GHG emissions associated with manufacturing and transportation of various inputs, and the scarcity and competition for various resources (e.g. phosphorus, water) suggest re-designing the system to have closer integration between livestock and crops, especially in developed countries. 
Table 2. Some examples of solutions to improve eco-efficiency by different approaches.

\begin{tabular}{|c|c|c|}
\hline & Technical and technological approach & Agro-ecological approach \\
\hline Genetics & $\begin{array}{l}\text { Increasing genetic merit (productivity, } \\
\text { productive efficiency, longevity, fertility) }\end{array}$ & $\begin{array}{l}\text { Choosing breeds adapted to the } \\
\text { ecosystem and to the climate, resilient } \\
\text { multi-purpose (e.g. milk and meat) breeds }\end{array}$ \\
\hline Nutrition & $\begin{array}{l}\text { Optimizing digestive functions, } \\
\text { improving metabolic efficiency for milk } \\
\text { secretion and muscle accretion, feeding } \\
\text { balanced rations that meet nutrient } \\
\text { requirements, using additives, adapting } \\
\text { feeding to reproduction cycle }\end{array}$ & $\begin{array}{l}\text { Using more feeds produced on farm, } \\
\text { diversifying feeds, use of co-products, } \\
\text { choosing reproduction periods according } \\
\text { to resources, providing adequate clean } \\
\text { water }\end{array}$ \\
\hline Animal health & $\begin{array}{l}\text { Conceiving healthy diets, monitoring } \\
\text { animal activities, using quick and } \\
\text { efficient disease diagnostic, monitoring } \\
\text { and control methods }\end{array}$ & $\begin{array}{l}\text { Using natural products against parasites } \\
\text { and diseases and for enhancing immune } \\
\text { response by animals, improving animal } \\
\text { and farm hygiene, taking care of animal } \\
\text { comfort }\end{array}$ \\
\hline Use of resources & $\begin{array}{l}\text { Preferring feeds with low environmental } \\
\text { impacts including low water and land } \\
\text { use, managing herd to limit non- } \\
\text { productive animals }\end{array}$ & $\begin{array}{l}\text { Shifting from mineral to organic } \\
\text { fertilization, optimizing manure } \\
\text { application, favoring plant biodiversity }\end{array}$ \\
\hline Manure management & $\begin{array}{l}\text { Improving slurry storage (type, duration) } \\
\text { for lower losses, producing biogas }\end{array}$ & Better integrating crops and livestock \\
\hline
\end{tabular}

\section{Conclusion}

Defining sustainability for livestock farming is a challenge, because it requires balancing multiple and changing objectives of the three pillars of sustainability: profit, planet and people including ethics in an array of dimensions from local to global, which is not easy to achieve. There is a need and room for coexistence of very diverse systems, each of them being adapted to a set of environmental and socio-economical conditions in different parts of the world. In this paper, the diversity of these systems in terms of farm structure and natural resource use has been outlined, and the means through which their sustainability could be enhanced have been discussed. In any system, key to improving sustainability lies in improving the multiple criteria of efficiency of the animal and the herd. The challenge for policy makers is to elaborate with stakeholders the roadmaps for realization of livestock production systems that efficiently utilize natural resources while respecting ethical and socio-cultural dimensions of people, which may differ from region to region.

\section{References}

Alary, V., G. Duteurtre and B. Faye, 2011. Elevage et sociétés: les rôles multiples de l'élevage dans les pays tropicaux. In: Elevage en régions chaudes (Coulon J.B., Lecomte P., Boval M., Perez J.M., eds). INRA Prod. Anim. 24, $145-156$.

Basset-Mens, C. and H.M.G. van der Werf, 2005. Scenario-based environmental assessment of farming systems: the case of pig production in France. Agric. Ecosyst. Environ. 105, 127-144

Basset-Mens, C., S. Ledgard and M. Boyes, 2009. Eco-efficiency of intensification scenarios for milk production in New Zealand. Ecol. Econ., 68, 1615-1625.

Blanc, F., F. Bocquier, J. Agabriel, P. D'Hour and T. Chilliard, 2006. Adaptive abilities of the females and sustainability of ruminant livestock systems. A review. Anim. Res. 55, 489-510. 
Blanfort, V., M. Doreau, J. Huguenin, J. Lazard, V. Porphyre, J.F. Soussana and B. Toutain, 2011. Impacts et services environnementaux de l'élevage en régions chaudes. In : Elevage en régions chaudes (Coulon J.B., Lecomte P., Boval M., Perez J.M., eds). INRA Prod. Anim. 24, 89-112.

Bocquier, F. and E. González-Garcia, 2010. Sustainability of ruminant agriculture in the new context: feeding strategies and features of animal adaptability into the necessary holistic approach. Animal 4, 1258-1273.

Cunningham, E. P., 2005. The genetic dimension. In: Knowledge agriculture: perspectives towards a new model of milk production. R. Keenan \& Co., Co. Carlow, Ireland, 9-11.

Darnhofer, I., S. Bellon, B. Dedieu and R. Milestad, 2010. Adaptiveness to enhance the sustainability of farming systems. A review. Agron. Sustain. Dev. 30, 545-555.

De Boer, I.J.M., 2003. Review. Environmental impact assessment of conventional and organic milk production. Livest. Prod. Sci. 80, 69-77.

De Vries, M. and I.J.M. de Boer, 2010. Comparing environmental impacts for livestock products: A review of life cycle assessments. Livest. Sci. 128, 1-11.

Doreau, M. and J.B. Dollé, 2011. Strategies for reducing greenhouse gas emissions in dairy production. A European perspective. Proc. 47th Eastern Nutrition Conference, Montréal, Canada, 55-77.

Doreau, M., H.M.G. van der Werf, D. Micol, H. Dubroeucq, J. Agabriel, Y. Rochette and C. Martin, 2011. Enteric methane production and greenhouse gases balance of diets differing in concentrate in the fattening phase of a beef production system. J. Anim. Sci. 89, 2518-2528.

Doreau, M., M.S Corson and S.G. Wiedemann, 2012. Water use by livestock: a global perspective for a regional issue? Anim. Front., 2 (2), 9-16.

Dumont, B., L. Fortun-Lamothe, M. Jouven, M. Thomas and M. Tichit, 2013. Prospects from agroecology and industrial ecology for animal production in the 21 st century. Animal, 7, 1028-1043.

Fanchone, A., P. Nozière, J. Portelli, B. Duriot, V. Largeau, M. Doreau, 2013. Effects of nitrogen underfeeding and energy source on digestion, nitrogen partition, and milk production in dairy cow. J. Anim. Sci. 91, 895-906.

FAO, 2009. The state of food and agriculture. Livestock in the balance. FAO, Rome, Italy, $166 \mathrm{p}$.

FAO, 2010. Greenhouse gas emissions from the dairy sector: A Life Cycle assessment. FAO, Rome, Italy, 94 pp.

FAO, 2012. Biofuel co-products as livestock feed. Opportunities and challenges (H.P.S. Makkar, ed). FAO, Rome, Italy, $534 \mathrm{p}$.

Gerber, P., N. Key, F. Portet and H. Steinfeld, 2010. Policy options in addressing livestock's contribution to climate change. Animal 4, 393-406.

Gill, M., P. Smith and J.M. Wilkinson, 2010. Mitigating climate change: the role of domestic livestock. Animal 4, 323-333.

Hodges, R.J., J.C. Buzby and B. Bennett, 2011. Postharvest losses and waste in developed and less developed countries : opportunities to improve resource use. J. Agric. Sci. 149 (S1), 37-45.

IPCC, 2007. Agriculture. In Climate Change 2007: Mitigation. Contribution of Working Group III to the Fourth Assessment Report of the IPCC on Climate Change (B. Metz, O.R. Davidson, P.R. Bosch, R. Dave, L.A. Meyer, eds), Cambridge University Press, UK.

Kounina, A., M. Margni, J.B. Bayart, A.M. Boulay, M. Berger, C. Bulle, R. Frischknecht, A. Koehler, L. Milà i Canals, M. Motoshita, M. Núñez, G. Peters, S. Pfister, B. Ridoutt, R. van Zelm, F. Verones and S. Humbert, 2013. Review of methods addressing freshwater use in life cycle inventory and impact assessment. Int. J. Life Cycle Assess. $18,707-721$.

Lebacq, T., P.V. Baret and D. Stilmant, 2013. Sustainability indicators for livestock farming. A review. Agron. Sustain. Dev. 33, 311-327.

Moran, D., M. MacLeod, E. Wall, V. Eory, G. Pajot, R. Matthews, A. McVittie, A. Barnes, B. Rees, A. Moxey, A. Williams, P. Smith, 2008. UK marginal abatement cost curves for the agriculture and land use, land-use change and forestry sectors out to 2022, with qualitative analysis of options to 2050. Report to the Committee of Climate Change, SAC, Edinburgh, UK.

Mosnier, C., J. Agabriel, M. Lherm and A. Reynaud, 2010. A dynamic bio-economic model to simulate optimal adjustments of suckler cow farm management to production and market shocks in France. Agric. Syst. 102, 77-88.

Mosnier, E., H.M.G. van der Werf, J. Boissy and J.Y. Dourmad, 2011. Evaluation of the environmental implications of the incorporation of feed-use amino acids in the manufacturing of pig and broiler feeds using Life Cycle Assessment. Animal 5, 1972-1983. 
Murgueitio, E., Z. Calle, F. Uribe, A. Calle and B. Solorio, 2011. Native trees and shrubs for the productive rehabilitation of tropical cattle. ranching lands. Forest Ecol, Manag. 261, 1654-1663.

Nanda, S.K., R. K. Vishwakarma, H.V.L. Bathla, A. Rai and P. Chandra, 2012. Harvest and post harvest losses of major crops and livestock produce in India. All India Coordinated Research Project on Post Harvest Technology (ICAR), Ludhiana. pp. 137, September 2012.

Nguyen, T.T.H., H.M.G. van der Werf and M. Doreau, 2012a. Life cycle assessment of three bull-fattening systems: effect of impact category on ranking. J. Agric. Sci., 150, 755-763.

Nguyen, T.T.H., M. Doreau, M. Eugène, M.S. Corson, F. Garcia-Launay, G. Chesneau and H.M.G. van der Werf, $2012 \mathrm{~b}$. Effect of type of ration and allocation methods on the environmental impacts of beef-production systems. Livest. Sci. 145, 239-251.

Nguyen, T.T.H., M. Doreau, M. Eugène, M.S. Corson, F. Garcia-Launay, G. Chesneau and H.M.G. van der Werf, 2013. Effect of farming practices for greenhouse gas mitigation and subsequent alternative land-use on environmental impacts of beef-cattle production systems. Animal, 7, 860-869.

Parfitt, J., M. Barthel and S. Macnaughton, 2010. Food waste within food supply chains : quantification and potential for change to 2050. Phil. Trans. R. Soc. B. 365, 3065-3081.

Reynolds, C.K., L.A. Crompton and J.A.N. Mills, 2011. Improving the efficiency of energy utilisation in cattle. Anim. Prod. Sci 51, 6-12.

Ripoll-Bosch, R., I.J.M. de Boer, A. Bernués and T. Vellinga, 2013. Accounting for multi-functionality of sheep farming in the carbon footprint of lamb: A comparison of three contrasting Mediterranean systems. Agric. Syst. 116, 60-68.

Robinson, T.P., P.K. Thornton, G. Franceschini, R.L. Kruska, F. Chiozza, A. Notenbaert, G. Cecchi, M. Herrero, M. Epprecht, S. Fritz, L. You, G. Conchedda and L. See, 2011. Global livestock production systems. FAO, Rome, Italy, and ILRI, $152 \mathrm{pp}$.

Scollan, N.D., D. Moran, E.J. Kim, and C. Thomas, 2010. The environmental impact of meat production systems. Report to the International Meat Secretariat, 65 p., http://www.meat-ims.org/old-site/IMSReview-final-20710.pdf

Steinfeld, H., P. Gerber, T. Wassenaar, V. Castel, M. Rosales and C. de Haan, 2006. Livestock's long shadow: environmental issues and options. FAO, Rome, Italy, $390 \mathrm{p}$.

Thornton, P.K., 2010. Livestock production: recent trends, future prospects. Phil. Trans. R. Soc. B. 365, 2853-2867.

UNFCCC, 2008. Challenges and opportunities for mitigation in the agricultural sector. Technical paper FCCC/ $\mathrm{TP} / 2008 / 8,101 \mathrm{p}$.

Vieux, F., N. Darmon, D. Touazi and L.G. Soler, 2012. Greenhouse gas emissions of self-selected individual diets in France: Changing the diet structure or consuming less? Ecol. Econ. 75, 91-101. 


\section{Energy and protein metabolism and nutrition in sustainable animal production}

$4^{\text {th }}$ International Symposium on Energy and Protein Metabolism and Nutrition Sacramento, California, USA

9-12 September 2013

EAAP publication No. 134

edited by:

James W. Oltjen

Ermias Kebreab

Hélène Lapierre

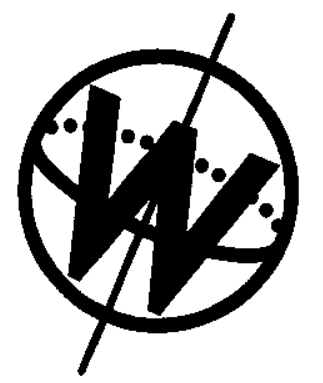

Wageningen Academic P u b I i $h$ e $r s$ 